\title{
Quality assessment of the physicochemical properties of vermiwash produced from different sources during successive storage periods
}

\author{
SIRPAUL JAIKISHUN ${ }^{1,2}$, SHAMIKA ADONIS ${ }^{1}$, ABDULLAH ADIL ANSARI ${ }^{1, \bullet}$ \\ ${ }^{1}$ Department of Biology, Faculty of Natural Sciences, University of Guyana. Turkeyen Campus, Greater Georgetown, Guyana. Tel.: +592-222-5423, \\ Fax.: +592-222-5122, •email: abdullah.ansari@uog.edu.gy \\ ${ }^{2}$ Haxia Institute of Science and Technology (HIST), Life Sciences College, Fujian Agriculture and Forestry University, Fuzhou, China
}

Manuscript received: 3 December 2018. Revision accepted: 22 December 2018.

\begin{abstract}
Jaikishun S, Adonis S, Ansari AA. 2018. Quality assessment of the physicochemical properties of vermiwash produced from different sources during successive storage periods. Asian J Agric 2: 52-57. Organic farming is crucial for not only maintaining our health, but with improving quality and quantity of crop production in environmentally friendly farming practices. Vermiwash is poised to be one of the key components in organic farming and reducing the enormous amounts of pollutants from the environment. This study aimed to determine the physicochemical characteristics related to vermiwash from different sources (Jamun, Neem and Grass with combination and mixed with cattle dung) during a three-month storage period with monthly assessments and compared to a fresh sample. While an increase in Electrical Conductivity (EC) was seen in the first month, successive decreases were noted thereafter with a significant difference $(\mathrm{p}=0.05)$ being observed among the treatments $(\mathrm{p}=0.05)$ after three months. Total dissolved salts decreased over the storage period with significant difference being observed among the treatments and storage period revealed that at $\mathrm{p}=0.05, \mathrm{~F}(7,21)$ $=3.9>2.49$ Fcrit. and $\mathrm{F}(3,21)=3.8>2.49$ respectively. Phosphorous decreased, while potassium increased with T7 having the highest. Calcium showed a significant difference $(\mathrm{p}=0.05)$ among the treatments, while magnesium fluctuated during the period but deceased at the end of the storage period. Analysis of ferrous content revealed a significant difference $(p=0.05, F(7,21)=3.8>2.48$ Fcrit. $)$ with the time being significantly different $(p=0.05, F(3,21)=6.8>3.0)$ with an increase at the end of the storage period. Fresh form of vermiwash is best to use to obtain maximum nutrients as the general nutrient composition deteriorates over time.
\end{abstract}

Keywords: Cattle dung, vermicompost, micronutrients, organic materials, soil, vermiwash

\section{INTRODUCTION}

There is an ever-growing global manifestation of the detrimental impacts of waste disposal. Many kinds of waste are produced daily. Some are useful and can be recycled in different fields, such as agriculture and other productive industries. One such is organic waste used to produce biofertilizers. Organic waste disposal from different sources like domestic, agriculture, and industrial has been a cause of concern for us since they create unaesthetic and unhealthy environment for the inhabitants. This results in environmental and economic problems for both urban and rural populations. Recycling of organic waste can be necessitated in the production of useful organic manure for agricultural applications (Aira et al. 2007; Ansari 2012).

Composting is becoming a very common technique in recycling organic waste, thereby increasing in productivity of food in an environmentally friendly way (Ansari and Jaikishun 2010; Ansari 2012). Various composting techniques offer solutions to the organic waste produced daily. One such technique is vermicomposting that not only reduces the organic waste but also promotes agricultural development in a more efficient, economical, and environmentally friendly manner (Ismail 2005; Ansari 2012; Manyuchi et al. 2012). Vermicomposting is a method of making compost by using earthworms which generally live in the soil, eat biomass, and excrete earthworm cast. The earthworms fragment the organic substrates, stimulate microbial activity significantly and increase rates of mineralization. Vermicompost is a finely divided peat-like material with excellent structure, porosity, aeration, drainage, and moisture holding capacity (Domínguez 2004; Ismail 2005; Ansari 2012; Manyuchi et al. 2012). Vermiwash is a liquid fertilizer collected after the passage of water through a column of worm action and may be used as a foliar spray (Ismail 2005; Ansari 2011).

Jamun \{Syzygium cumini (L.) Skeels\} is a very common tree found in Guyana. It belongs to the family Myrtaceae. The leaves of this tree range from being entire to lanceolate. The leaves are comprised of $9.1 \%$ crude protein, $4.3 \%$ fat, $17 \%$ crude fiber, $1.3 \%$ calcium and $0.29 \%$ phosphorous. The leaves are believed to have medicinal properties (Datta 1969). Neem (Azadirachta indica A. Juss) is another good source of food for earthworms. It belongs to the family Meliaceae. Neem is beneficial to earthworms. Neem leaves and seed kernels increased the number of earthworms in the potting soil in greenhouses. Neem is rich in nutrients, which also aid the fatter growth of earthworms. Another study conducted showed that vermicomposting of neem is accomplished at a high rate since the earthworm densities are quite high as compared to vermicomposting using mango leaves (Datta 1969). Earthworms contribution to the soil is in the form of organic carbon, nitrogen, inorganic phosphorus, potassium, magnesium among others in the excreta or worm casts 
(Hendrix and Bohlen 2002; Ansari 2011; Picón and Teisaire 2012).

Vermiwash is a liquid that is collected after the passage of water through a column of worm-worked soil and is very useful as a foliar spray. It is a collection of excretory and secretory products of earthworms, along with micronutrients of the soil and soil organic molecules that are useful for plants. Vermiwash also acts as a mild biocide (Ansari 2012). Magnesium, chloride, calcium, organic carbon, nitrate, nitrogen, phosphorous and carbon are the major nutrients found in vermiwash. Carbohydrates, proteins, lipids, and amino acids are other nutrients that are found in vermiwash (Ansari and Jaikishun 2010; Sundaravadivelan et al. 2011; Ansari 2012).

\section{MATERIALS AND METHODS}

\section{Materials}

Vermiwash units were set up at the University of Guyana, at the Faculty of Natural Sciences, Biology laboratory. The mature leaves (Grass clippings, Neem and Jamun leaves) were collected from the university campus and air dried completely before adding to the vermiwash unit. Cattle dung was obtained from NARIE (National Agricultural Research and Extension Institute, Guyana) Chemical analyses of vermiwash were done at the Guyana Sugar Corporation Central Laboratory. Conversion of vermiwash into powdered form and storage was executed at the University of Guyana's biology laboratory.

\section{Procedures}

The vermiwash unit was set up using nine buckets. The buckets were fixed with taps about an inch from the bottom and placed on a stand to facilitate collection. A $25 \mathrm{~cm}$ of broken pebbles were placed at the bottom of each bucket, which was followed by a $25 \mathrm{~cm}$ layer of coarse sand. Water was then allowed to flow through these layers to enable the settling of the basic filter bed. A 20-30 cm layer of loamy soil was placed on top of the filter bed. Earthworms (25) were introduced into the soil, for the eight buckets. Cattle dung $(150 \mathrm{~g})$ and selected organic (75g-total) materials in specified quantities were placed on top of the soil in the buckets with the earthworms (Control - Cattle dung, T1Grass clippings, T2-Neem leaves, T3-Jamun leaves, T4Grass clippings + Neem leaves, T5-Neem + Jamun leaves, T6-Grass clippings + Jamun leaves, T7-Grass clippings+ Neem + Jamun leaves). The units were irrigated and drained every two days to maintain moisture for the earthworms. Units were monitored and specified quantities of organic material were added every month (Ansari and Jaikishun 2010; Ansari 2012).

\section{Collection and storage of vermiwash}

After four months of setting up and maintaining units, $300 \mathrm{ml}$ of vermiwash was collected. The collected vermiwash was placed into bottles, of the same size, for storage in a cool, dry, and dark place. Storage took place over a 3-month period to determine its effectiveness. Vermiwash from different organic materials was collected and stored every month. Vermiwash collected was tested monthly for the following physicochemical properties: $\mathrm{pH}$, electrical conductivity, total dissolved salts, turbidity, nitrogen, available phosphate, potassium, exchangeable calcium, exchangeable magnesium, iron, and manganese (Homer 2003; AOAC 2012).

\section{RESULTS AND DISCUSSION}

A decrease in electrical conductivity (EC) was noted after three months of storage. It was seen that $\mathrm{T} 1$ showed a decrease but had a minimal increase for the $3^{\text {rd }}$ month of storage. $\mathrm{T} 2$ had a significant increase in the first month, but then decreased after the $2^{\text {nd }}$ and $3^{\text {rd }}$ months, similar trend in noticed in T5. T4 showed an increase in the $2^{\text {nd }}$ and $3^{\text {rd }}$ months but decreased in the final month. However, treatments 3 and 7 had an increase in electrical conductivity in which $\mathrm{T} 7$ had a significant increase. An increase in $\mathrm{T} 7$ was because of the combination of organic material used, which caused an increase in the number of ions present in the sample (Figure 1). Anova Two-Factor without replication analyses for EC among the treatments and time indicated significant difference with $p=0.05, F$ (7, $21)=3.7>2.49$ Fcrit. and $\mathrm{F}(3,21)=3.5>3.1 \quad F$ crit respectively. According to Najar and Khan (2010), the increase in EC might have been due to the loss of weight of organic matter and release of different mineral salts in available forms such as: phosphate, ammonia, and potassium. Further, the increase of ions means an increase in electrical conductivity of a solution. The more dissolved solids that are present, the higher the conductance of the solution. This is because the solids dissolve into positively and negatively charged ions that can conduct an electrical current proportional to their concentration. Electrical conductivity is the basis of determining the presence of solids in a solution such as potassium, magnesium, calcium, etc. The decreased EC may mean that the amount of available soluble solids such as salts (ions) may be low in the vermiwash samples. A decrease in EC may be due to the increased rate of loss of organic matter and consequently release of different minerals salts (Chauhan and Singh 2012).

There is an increase in the $\mathrm{pH}$ after three months (Figure 2). It is seen that for the control there was an increase for the $1^{\text {st }}$ month then a gradual decrease after the $2^{\text {nd }}$ month. T1, T2, T4, T5, T6, and T7 showed a gradual increase in $\mathrm{pH}$ throughout the 3 -month period, however, for $\mathrm{T} 3$ there was an increase for the $1^{\text {st }}$ month then a decrease after the $1^{\text {st }}$ and $2^{\text {nd }}$ months. Earthworms contribute several nutrients in the form of nitrogenous wastes. Anova TwoFactor without replication analyses for sample $\mathrm{pH}$ among the treatments and time showed a significant difference with $p=0.05, F(7,21)=4.6>2.48$ Fcrit. and $F(3,21)=$ 4.9>3.1 Fcrit. respectively. According to Najar and Khan (2010), the increase in $\mathrm{pH}$ with time interval, is due to the decomposition of ammonia, which forms a large proportion of nitrogenous matter excreted by earthworms. The $\mathrm{pH}$ regulates the rate of dissolution of substances, and thus absorption. Soil $\mathrm{pH}$ is one of the most important soil 
properties that affect the availability of nutrients. Macronutrients tend to be less available in soils with low $\mathrm{pH}$, and micronutrients tend to be less available in soils with high $\mathrm{pH}$. Thus, it is necessary for vermiwash to have $\mathrm{pH}$ when added to the soils to promote absorption of nutrients (Domínguez 2004; Ansari and Rajpersaud 2012; Degefe et al. 2012).

An overall decrease in total dissolved salts in vermiwash was observed after storage for 3 months. T1 and the control showed an overall decrease, however, there was an increase after the $1^{\text {st }}$ month for the rest of the samples, and a subsequent decrease at the $2^{\text {nd }}$ month. However, T4 showed a major increase in the $2^{\text {nd }}$ month and a subsequent decrease in the $3^{\text {rd }}$ month. T7 had a major increase in the $3^{\text {rd }}$ month. There were fluctuating changes in total dissolved salts content; nevertheless, there was an overall decrease in total dissolved salts (Figure 3). Since total dissolved salts are related to electrical conductivity, then a decrease in TDS may be due to increased rate of loss of organic matter. And consequently, a release of different minerals salts. Anova Two-Factor without replication analyses for TDS among the treatments and time revealed that at $p=0.05, F$ $(7,21)=3.9>2.49$ Fcrit. and $\mathrm{F}(3,21)=3.8>2.49$ respectively with significant difference. TDS are the inorganic dissolved solids in a liquid and therefore incorporate dissolved ionic minerals. Both anions (such as phosphates, fluorine, and chlorine) and cations (such as magnesium, calcium, iron, nitrogen, and potassium) are important constituents. An increase in total dissolved salts may contribute to a decrease in photosynthesis in plants (Datta 1969; Jensen 1999; Domínguez 2004; Degefe et al. 2012).

There was a general increase in turbidity of vermiwash after three months. However, a decrease in turbidity was noted in the $1^{\text {st }}$ month and subsequently increased in the $2^{\text {nd }}$ and $3^{\text {rd }}$ months a common trend. There was fluctuation for the samples amidst the overall increase in turbidity (Figure 4). Anova Two-Factor without replication analyses for turbidity among the treatments and time revealed that at $p=0.05, \mathrm{~F}(7,21)=2.6>2.5$ Fcrit. and $\mathrm{F}(3,21)=4.1>2.2$ respectively with significant difference, an indication that with time and the different treatments more insoluble substances are released. Suspended materials in a liquid may reduce water and cause turbidity (Tiwari 2015).

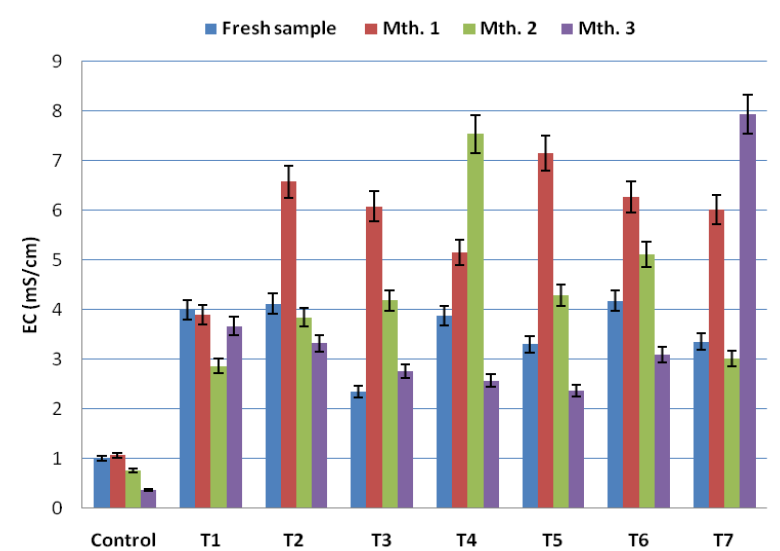

Figure 1. Effect of storage period on the Electrical conductivity

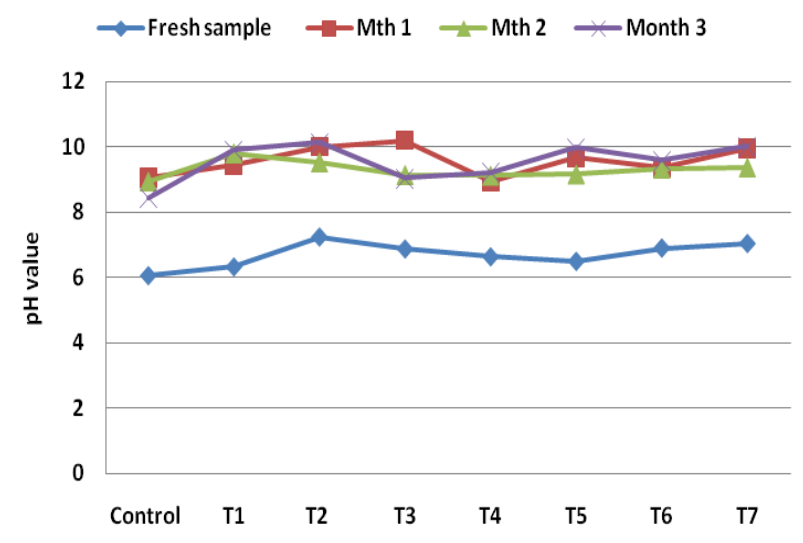

Figure 2. Effect of storage period on the $\mathrm{pH}$ of vermiwash

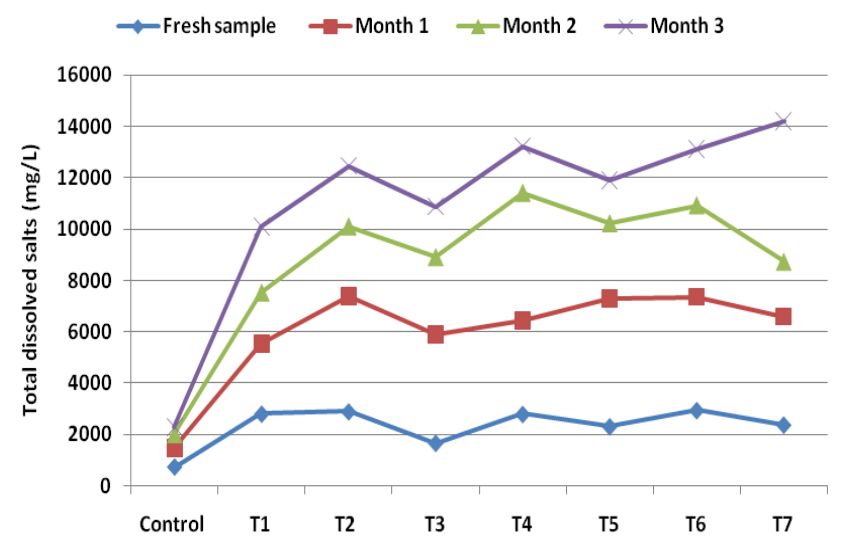

Figure 3. Effect of storage period on the Total Dissolved Salts (TDS)

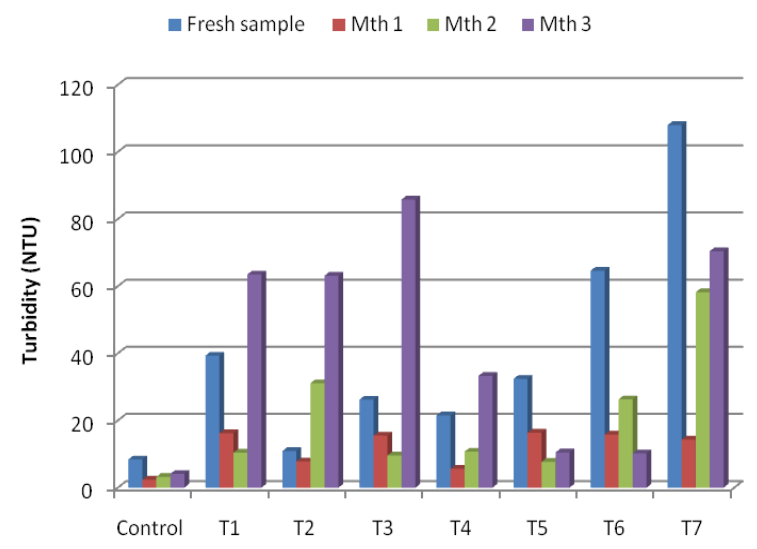

Figure 4. Effect of storage period on the turbidity of vermiwash mixture 


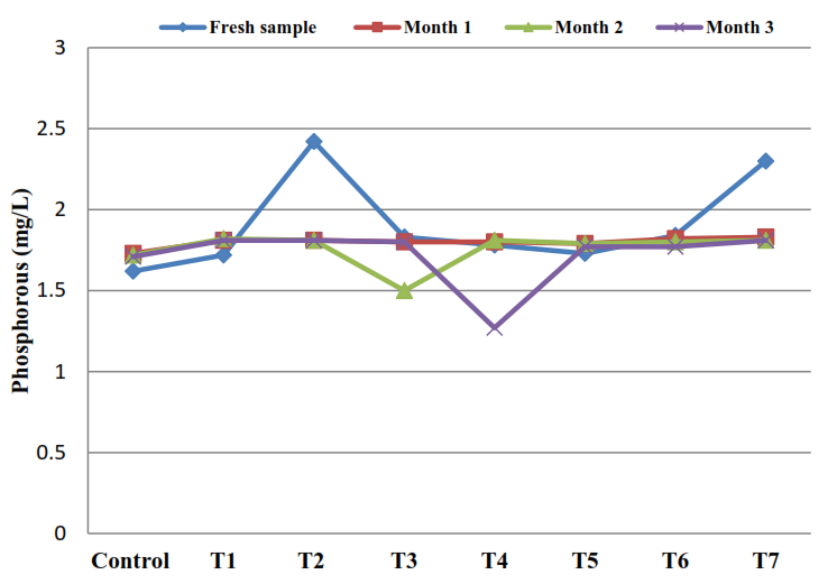

Figure 5. Phosphorous content of vermiwash during the storage period

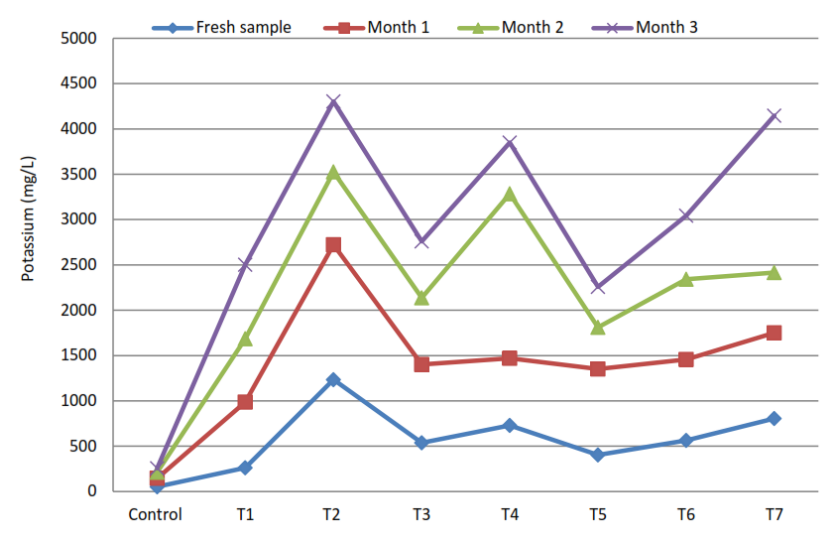

Figure 6. Potassium content during the storage period

There was an overall decrease in phosphorous content over the three-month period for majority of the treatments. For the control, there was a gradual increase then a small decrease in phosphorous after the $3^{\text {rd }}$ month. Even though there was a fluctuating pattern in the amount of potassium found in T2, T3, T4, and T6 it was subsequently seen that there was a decrease after the three months of storage of vermiwash. T1 and T5, however, showed an increase after the $3^{\text {rd }}$ month but this increase was quite small (Figure 5) Anova Two-Factor without replication analyses for $\mathrm{P}$ among the treatments and the three-month period indicated no significant difference with $p=0.05, \mathrm{~F}(7,21)=1.5<2.48$ Fcrit and $F(3,21)=1.8<3.1$ respectively. Similarly, Khwairakpam and Bhargava (2007) observed a decrease in $\mathrm{P}$ and attributed it to the mineralization of organic phosphorus and consumption by microbes. The passage of organic matter through the gut of a worm, results in phosphorus being converted to more bio-available forms. This is done by both worm's gut enzyme 'phosphatases' and by the phosphate solubilizing microorganisms in the worm cast (Nath et al. 2009; Degefe et al. 2012).

There was an increase in potassium content for T1, T3, T5, T6, and T7. However, T2 and T4 showed a major decrease after the $3^{\text {rd }}$ month. There was a fluctuation in the amount of $\mathrm{K}$ observed in the units T1, T3, T5, T6, and T7 but at the end of the three-month period, a general increase was observed. T1 and T5 showed a major increase, whilst T3 and T6 had a slight increase of $\mathrm{K}$ content. T7 had a dramatic increase due to the combination of all organic materials used while the control showed a decrease in potassium content. However, there was an overall increase in $\mathrm{K}$ (Figure 6). Anova Two-Factor without replication analyses for $\mathrm{K}$ among the treatments indicated a significant difference $(p=0.05, \mathrm{~F}(7,21)=4.0>2.48$ Fcrit. $)$ while with time, there was an insignificant difference $(p=0.05, F(3$, $21)=0.9<3.12$ Fcrit.) observed. According to Nath et al., (2009) earthworm processed waste material contains high concentration of exchangeable potassium, due to enhanced microbial activity during the vermicomposting process, which consequently enhanced the rate of mineralization. The increased potassium content is due to large number of symbiotic microflorae present in the gut and the cast of earthworms in collaboration with secreted mucus and water. This might increase the degradation of ingested organic matter and the release of assailable metabolites. These metabolites enhanced the enrichment of the vermiwash with exchangeable potassium. The decrease in potassium in T2 and T4 may be because of leaching of this soluble element, after water was applied for collection (Ansari and Rajpersaud 2012; Chauhan and Singh 2012; Degefe et al. 2012).

For the control, there was a general decrease in calcium content. There was an overall increase in calcium content for samples T1, T2, T4, T5 and T6. T1 and T2 showed a gradual decrease while $\mathrm{T} 4$ and $\mathrm{T} 5$ showed a great increase for both months 1 and 2, then decreased greatly for the 3rd month. T6 showed fluctuation in value, however, decreased after the final month. T3 and T7 also had a fluctuating change in value however there was an increase in calcium content for the $3^{\text {rd }}$ month. Anova Two-Factor without replication analyses for $\mathrm{Ca}$ among the treatments revealed a significant difference $(p=0.05, F(7,21)=3.3>2.48$ Fcrit. $)$ while with time had no significant difference $(p=0.05, \mathrm{~F}(3$, $21)=2.8>3.0$ Fcrit.). It is suggested that this increase is due to gut processes, associated with calcium metabolism, which is primarily responsible for enhanced content of inorganic Ca content in worm cast (Najar and Khan 2010). A percentage decrease in calcium could be because of leaching of this soluble element by the excess water that is drained through for collection \{Table 1\} (Domínguez 2004; Najar and Khan 2010; Degefe et al. 2012).

Table 1. Percentage change in $\mathrm{Ca}, \mathrm{Mg}$ and $\mathrm{Fe}$ during the storage period

\begin{tabular}{lccc} 
Treatment & \multicolumn{3}{c}{ Content change (\%) } \\
& Ca & Mg & Fe \\
\hline Ck & 67.25 & -4.20 & -99.18 \\
T1 & 56.56 & 101.25 & 1190.59 \\
T2 & 42.01 & 60.39 & 364.84 \\
T3 & -8.95 & 198.12 & 544.59 \\
T4 & 47.77 & 52.04 & 45.96 \\
T5 & 57.11 & 24.12 & -17.78 \\
T6 & 7.066 & 203.35 & 1231.72 \\
T7 & -18.38 & 201.59 & 480.48 \\
\hline
\end{tabular}


There was an overall percentage increase for magnesium for all the samples. For the control, there were fluctuating changes, however, a final decrease in $\mathrm{Mg}$ content was observed. All the samples, excluding T1, showed a major increase for the $1^{\text {st }}$ month. However, there was a decrease in the $2^{\text {nd }}$ month then increased during the $3^{\text {rd }}$ month. T3, T4, and T5, however, showed a decrease instead of an increase in $\mathrm{Mg}$ content after the $3^{\text {rd }}$ month (Table 1). Anova Two-Factor without replication analyses for $\mathrm{Mg}$ among the treatments revealed a significant difference $(p=0.05, F(7,21)=5.7>2.48$ Fcrit. $)$ with the time being significantly different $(p=0.05, F(3,21)=$ 8.12>3.0 Fcrit.) as well. The increase of $\mathrm{Mg}$ may be due to the conversion of this nutrient to plant available form during passage through the earthworm gut (Najar and Khan 2010; Ansari 2011; Degefe et al. 2012).

There was a general increase in iron for all the treatments however for $\mathrm{T} 5$ there was a decrease after the third month when compared to the fresh sample. There was a fluctuating change for all the treatments but an eventual increase in $\mathrm{Fe}$ content. Anova Two-Factor without replication analyses for $\mathrm{Fe}$ among the treatments revealed a significant difference $(p=0.05, F(7,21)=3.8>2.48$ Fcrit. $)$ with the time being significantly different $(p=0.05, \mathrm{~F}$ (3, $21)=6.8>3.0)$. Iron $(\mathrm{Fe})$ is one of the main nutrients needed for the biosynthesis of chlorophyll (Quaik et al. 2012).

Vermiwash obtained from the different organic sources (Jamun, Neem leaves, Grass clippings, and Cattle dung) was found to be highly efficient with the necessary macro and micronutrients. Physicochemical analysis of the different treatments showed excellent content of the nutrients required for successful plant growth and development. The macro and micronutrients present in vermiwash are essential and easily available to plants. This has been proven by previous research. The physicochemical, nutritional, and biochemical parameters of vermiwash were produced from different leaf litters by using two earthworm species. Vermiwash is highly efficient in not only essential nutrients for plants but also carbohydrate, protein, lipid, and amino acid which are also important factors for plant growth (Ansari 2008; Ansari and Sukhraj 2010; Sundaravadivelan et al. 2011; Manyuchi et al. 2012).

Thus, the quality of vermiwash produced improved with duration of vermicomposting but varied with the leaf litter. Earthworms assimilate nutrients like energy, from a wide range of ingested materials with variable efficiency depending on the species and the nature of the ingested materials. The quality of vermiwash may also be a result of the use of organic material of plant and animal origin, which may be very efficient in nutrient quality. The organic degradable refuse of plant and animal origin have been shown to provide a good source of nutrients to improve crop productivity (Domínguez 2004; Ansari 2011; Sundaravadivelan et al. 2011; Degefe et al. 2012).

In conclusion, it is also seen that vermiwash is best in the first month, but the quality reduces with time. The physicochemical properties of vermiwash have excellent mineral content, with essential nutrients in desired quantities that may be readily available for plant growth. The quality of vermiwash produced with the use of leaf litter from three different plants namely Neem, Jamun, and Grass, clearly shows that the food quality largely influences the vermiwash potential. The quality of vermiwash produced may be due to the quality and type of organic material used. The organic degradable refuse of plant and animal origin, has shown to provide a good source of nutrients to improve productivity. Hence, making vermiwash can be very efficient in organic farming because of adequacy of nutrient composition for plant growth and simultaneously promoting positive attributes in the environment.

\section{REFERENCES}

Aira M, Monroy F, Domínguez J. 2007. Eisenia fetida (Oligochaeta: Lumbricidae) modifies the structure and physiological capabilities of microbial communities improving carbon mineralization during vermicomposting of pig manure. Microb Ecol 54: 662-671.

Ansari A. 2011. Worm-powered environmental biotechnology in organic waste management. Intl J Soil Sci 6: 25-30.

Ansari A. 2012. Vermitechnology-permutations and combinations of organic waste. LAP LAMBERT Academic Publishing Gmbh and Co. $\mathrm{KG}$, Germany.

Ansari A, Jaikishun S. 2010. An investigation into the vermicomposting of sugarcane bagasse and rice straw and its subsequent utilization in cultivation of Phaseolus vulgaris L. in Guyana. Amer-Eur J Agric and Environ Sci 8: 666-671.

Ansari A.A. 2008. Effect of vermicompost and vermiwash on the productivity of spinach (Spinacia oleracea), onion (Allium cepa) and potato (Solanum tuberosum). World J Agric Sci 4: 554-557.

Ansari A.A, Rajpersaud J. 2012. Physicochemical changes during vermicomposting of water hyacinth (Eichhornia crassipes) and grass clippings. ISRN Soil Sci. Article ID 984783, DOI: $10.5402 / 2012 / 984783$

Ansari A.A, Sukhraj K. 2010. Effect of vermiwash and vermicompost on soil parameters and productivity of okra (Abelmoschus esculentus) in Guyana. African J Agric Res 5: 1794-1798.

AOAC. 2012. "Official Methods. (A.O.A.C.). American Organisation of Agricultural Chemists, Washington, D.C., U.S.A.

Chauhan H.K, Singh K. 2012. Effect of binary combinations of buffalo, cow and goat dung with different agro wastes on reproduction and development of earthworm Eisenia fetida (Haplotoxida: Lumbricidae). World J Zool 7: 23-29.

Datta S. 1969. A Handbook of Systematic Botany. Asia Publishing House, Bombay.

Degefe G, Mengistu S, Dominguez J. 2012. Vermicomposting as a sustainable practice to manage coffee husk, Enset waste (Enset ventricosum), Khat waste (Catha edulis) and vegetable waste amended with cow dung using an epigeic Earthworm Eisenia andrei (Bouch'1972). Intl J PharmTech Res 4: 15.

Domínguez J. 2004. State-of-the-Art and New Perspectives on Vermicomposting Research. Earthworm Ecology, O· 8-193. 1819. XI04. CRC Press, Boca Raton, FL.

Hendrix P.F, Bohlen P.J. 2002. Exotic earthworm invasions in North America: ecological and policy implications: expanding global commerce may be increasing the likelihood of exotic earthworm invasions, which could have negative implications for soil processes, other animal and plant species, and importation of certain pathogens. AIBS Bull 52: 801-811.

Homer F. 2003. Soil Analysis Manuel. Central Analytical and Environmental Monitoring Services. Agriculture Research Department, LBI, Guyana,

Ismail S.A. 2005. The Earthworm Book. Other India Press, Mapusa, Goa. India.

Jensen M.H. 1999. Hydroponics worldwide. Acta Horticulturae 481: 719 729.

Manyuchi M.M, Phiri A, Chirinda N, Muredzi P, Govhaand J, Sengudzwa T. 2012. Vermicomposting of waste corn pulp blended with cow dung 
manure using Eisenia fetida. World Acad Sci Eng Technol 68: 13061309.

Najar I.A, Khan A.B. 2010. Vermicomposting of invasive species Azolla pinnata with Eisenia fetida. Bioscan 5: 239-241.

Nath G, Singh K, Singh D. 2009. Chemical analysis of vermicomposts/vermiwash of different combinations of animal, agro and kitchen wastes. Australian J Basic Appl Sci 3: 3672-3676.

Picón M.C, Teisaire E.S. 2012. Identification of the intestinal microbial community of Glossoscolecidae Earthworms (Annelida: Oligochaeta). Mun. Ent. Zool 7: 1035-1043.

Quaik S, Embrandiri A, Rupani P.F, Singh R.P, Ibrahim M.H. 2012 Effect of vermiwash and vermicomposting leachate in hydroponics culture of Indian Borage (Plectranthus ambionicus) plantlets. In: UMT 11th International Annual Symposium on Sustainability Science and Management, Held on 9-11 July 2012 at Kuala Terengganu, Malaysia.

Sundaravadivelan C, Isaiarasu L, Manimuthu M, Kumar P, Kuberan T, Anburaj J. 2011. Impact analysis and confirmative study of physicochemical, nutritional and biochemical parameters of vermiwash produced from different leaf litters by using two earthworm species. J Agric Technol 7: 1443-1457.

Tiwari S. 2015. Water quality parameters-A review. Intl J Eng Sci Invent Res Dev 1: 319-324. 